\title{
Compact Circular Ring Antenna for 5G Mobile Communication Applications
}

\author{
Sarah A. Alassawi 1,*, Wael A.E. Ali2,†, Mohamed R.M. Rizk ${ }^{3, \ddagger}$ \\ ${ }^{1}$ Electronics \& Comm. Engineering Department, College of Engineering, Higher Institute of Engineering \\ and Technology, King Marriott, Alexandria, Egypt \\ ${ }^{2}$ Electronics \& Comm. Engineering Department, College of Engineering, Arab Academy for Science, \\ Technology and Maritime Transport (AASTMT), Alexandria, Egypt \\ ${ }^{3}$ Electrical Engineering Department, Alexandria University, Alexandria, Egypt
}

(Received 21 March 2021; revised manuscript received 15 June 2021; published online 25 June 2021)

\begin{abstract}
This paper presents another alternative design of monopole microstrip patch antenna for millimeter wave (MMW) short range wireless communications applications. The purpose of this paper is to discuss a new design of antenna that operates in the MMW frequency range at $60 \mathrm{GHz}$. The design is based on single element with full size of $9 \times 11 \mathrm{~mm}^{2}$ that contains two elliptical loops monopole antenna and a line feed of $50 \mathrm{ohm}$ on the top layer of substate with a partial ground plane on the opposite side. Microstrip-patch antenna has been designed and implemented for 5G wireless communication technology at $60 \mathrm{GHz}$ with low-cost and small size substrate that makes it suitable for small devices. In the proposed design, the used substrate material is Roger RT6035htc lossy with relative dielectric 3.5 and loss tangent 0.0013 with partial ground plane to improve the impedance characteristics. The designed antenna provides a uniform current distribution over the surface of antenna at the resonance frequency with an acceptable realized gain of $4.8 \mathrm{dBi}$ in the far-zone with a return loss reaches up to $-33 \mathrm{~dB}$. The simulation results are carried out using high frequency structure simulator (HFSS), FEM is based on full 3D wave electromagnetic solver simulator from Analysis and the obtained results confirm the suitability of the proposed MMW antenna to be a good candidate for $5 \mathrm{G}$ applications.
\end{abstract}

Keywords: MMW, Monopole antenna, 5G mobile application, $60 \mathrm{GHz}$, Circular ring antenna, High frequency structure simulator (HFSS).

PACS number: 84.40.Ba

\section{INTRODUCTION}

To adapt the fast development in wireless mobile communication field, monopole antennas such as circular, square, triangular, rectangular, and rhombic are designed to improve and enhance the performance to reach the best radiation and gain characteristics and they are usually used as linearly polarized antennas [1]. There are several designs have been implemented at MM-wave applications, such as aperture-coupled patch antenna, slot patch antennas, multilayer antenna, multiple feed points, helical antenna and patch antenna incorporating an air cavity [2-4].

Nowadays, the millimeter wave radio frequency can provide the basic ground for the new generation (5G). It has operating frequencies spectrum ranges starting from $3 \mathrm{GHz}$ up to $300 \mathrm{GHz}$ to fulfill the needs of the new generation requirements. The frequency spectrum of $5 \mathrm{G}$ application is from $20 \mathrm{GHz}$ up to $90 \mathrm{GHz}$ [2]. The frequencies of $5 \mathrm{G}$ antennas are designed at $28 \mathrm{GHz}, 38 \mathrm{GHz}$, and $60 \mathrm{GHz}$. The antennas of $5 \mathrm{G}$ applications have a bandwidth of $500 \mathrm{MHz}$, $1 \mathrm{GHz}$, and $2 \mathrm{GHz}$. Hence, they are all suitable and compatible for high data rate and low latency systems [3]. Also, all antennas are preferred to be directional. In addition, they are sensitive to obstacles due to the narrow of the beam width [4]. Now, many substrates are available, and their dielectric constants are always working below $10 \mathrm{GHz}$ except Rogers substrate, which makes it suitable for ultrahigh frequencies because of low dielectric loss and low dispersion $[5,6]$.

This paper presents a dual circular rings monopole antenna which is implemented in MM-wave applications with a centered frequency at $60 \mathrm{GHz}$ and this makes it suitable for small devices. The used substrate material is Roger RT6035htc lossy with relative dielectric 3.5 and loss tangent 0.0013 .

The remaining sections of this paper are organized as follows: Section two describes the design of antenna parameters. The geometry and simulation results of the proposed antenna design are discussed in section three. The last section concludes the paper and highlights the performance features of the achieved design.

\section{ANTENNA DESIGN}

In recent years, it has been founded that monopole antennas are lightweight, low profile, and easy to be integrated with MMICs [7, 8]. Omnidirectional antennas are widely used in wireless communications system and very desirable for $60 \mathrm{GHz}$ antennas and they have been proposed for MMW applications [9]. These designs are either implemented in multilayer, LTCC technology or fused silica substrate [10]; some of these are not suitable for the high-volume consumer electronic market. Using the MMW antenna this problem can be mitigated while allowing for reduction in interference from multipath reflections.

\footnotetext{
*sarah.elesawy@gmail.com

$\dagger$ wael.ali@aast.edu

‡mrmrizk@ieee.org

The results were presented at the International Conference on Innovative Research in Renewable Energy Technologies (IRRET-2021)
} 

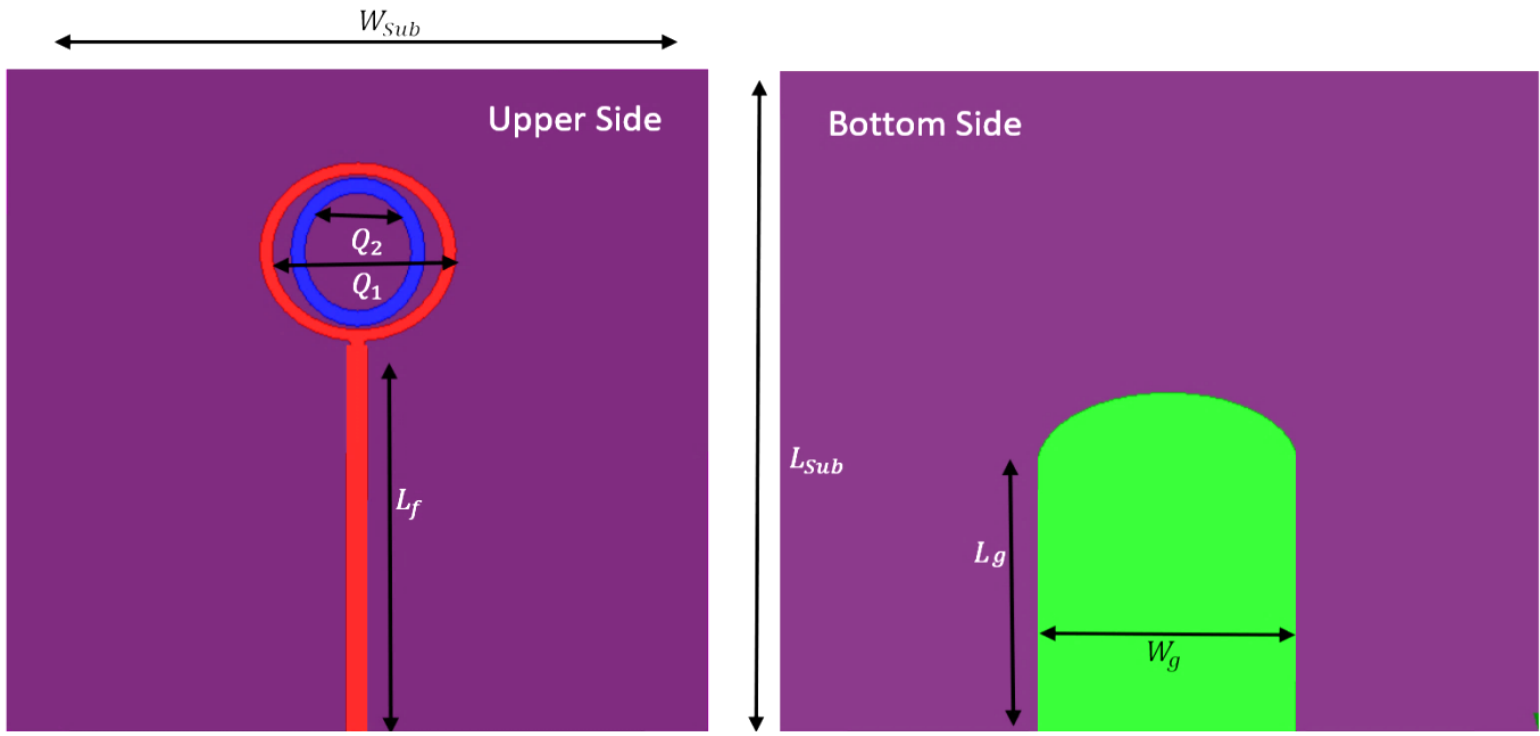

Fig. 1 - Single element patch antenna

\subsection{Circular-ring Antenna Design}

In 5G Mobile communication's applications, the operated frequency works at frequency range of $60 \mathrm{GHz}$ and monopole antenna in this paper is designed to work at the same frequency. Fig. 1 illustrates the dimensions of substrate width $W_{\text {sub }}=9 \mathrm{~mm}$, length $L_{s u b}=10 \mathrm{~mm}$ and thickness $0.25 \mathrm{~mm}$ with Rogers 6035 material having dielectric constant of $2.2 \mathrm{~mm}$, loss tangent of 0.0013 and relative permittivity 3.5. The patch dimensions are line feed $L_{f}=2.07 \lambda_{g}$, with two circular rings of radii $Q 1=0.48 \lambda_{g}$ and $Q 2=0.4 \lambda_{g}$, where $\lambda_{g}=\frac{\lambda_{r}}{\sqrt{\varepsilon_{e f f}}}$.

The partial ground plane of dimensions $W_{g}=3.4 \mathrm{~mm}$ and $L_{g}=3.5 \mathrm{~mm}$. In that design the partial ground plane is used to enhance the impedance characteristics by obtaining a deeper return loss at the resonance frequency and this is evident by the achieved results of Fig. 2.

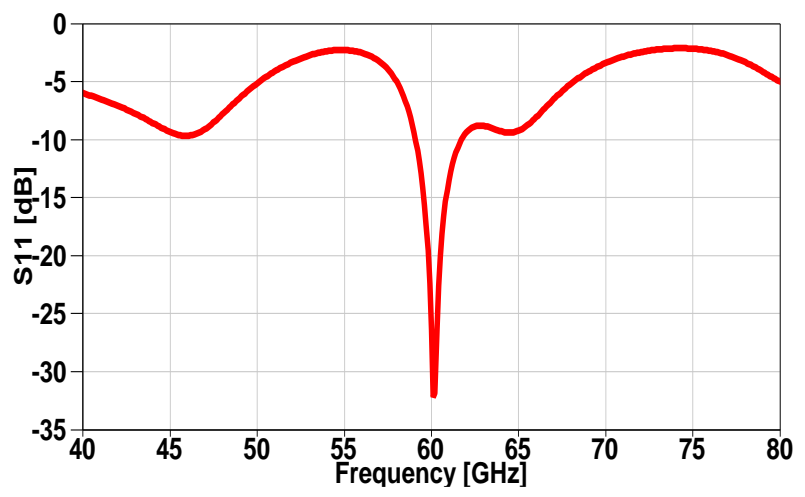

Fig. $2-S_{11}$ of a circular ring monopole antenna

\section{SIMULATION AND RESULTS}

This section presents simulation results such as return loss, current distribution, radiation pattern and gain of the monopole of 5G monopole antenna at $60 \mathrm{GHz}$. We start by studying the performance of the proposed monopole antenna shown in Fig. 1. It is evident from Fig. 2 that the return loss is $-33 \mathrm{~dB}$ at the resonance frequency of $60 \mathrm{GHz}$. The patch and the ground plane led the proposed single antenna to have a wider bandwidth than the one achieved in [1] by an increase in $5.24 \%$ in the same band.

For further explanation of the performance of monopole antenna, Fig. 3 shows the simulated surface current distribution for the proposed antenna design which is implemented at $60 \mathrm{GHz}$ [11]. The current distribution is mainly concentrated in the feed line and adjacent to both elliptic parasitic strips beside the feed line. The current is primarily distributed underneath the feed line.

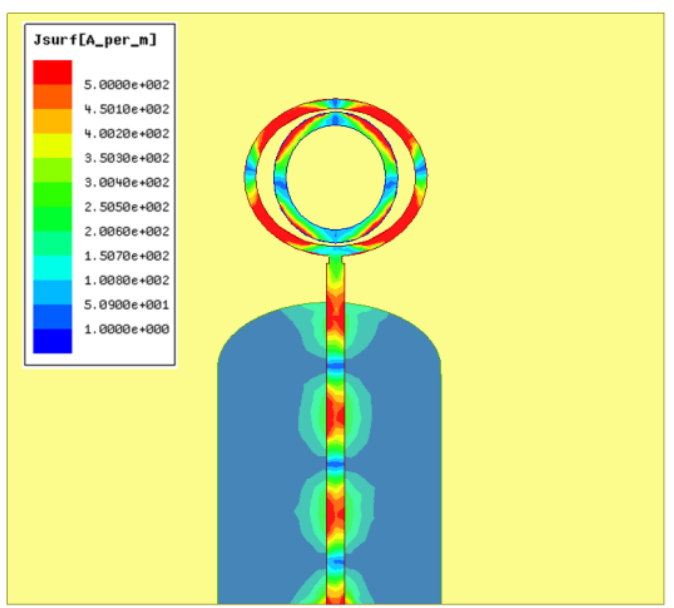

Fig. 3 - Current distribution of 5G monopole antenna at $60 \mathrm{GHz}$

Fig. 4 and Fig. 5 show the radiation characteristics of the dual rings patch antenna for 5G operation. The $2 \mathrm{D}$ and $3 \mathrm{D}$ radiation patterns are carried out at a frequency of $60 \mathrm{GHz}$. Fig. 4 claims that the antenna has a nearly omnidirectional normalized radiation pattern, and it achieves a high realized gain of $4.8 \mathrm{dBi}$ as shown in Fig. 5. It is worth noting that the obtained peak realized gain from this design is $4.8 \mathrm{dBi}$ confirming the suitability of the proposed design for $5 \mathrm{G}$ applications. 


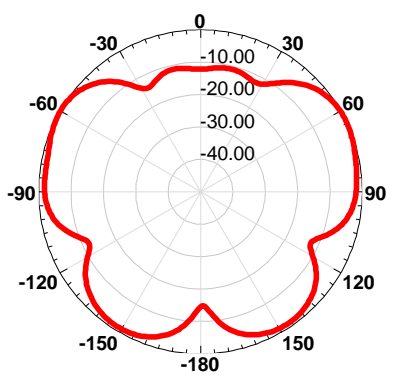

a

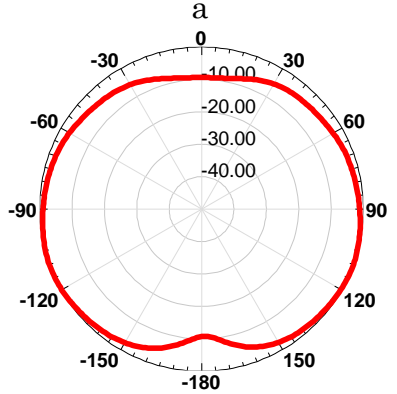

$\mathrm{b}$

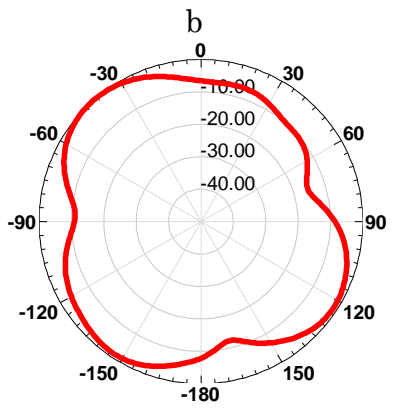

c

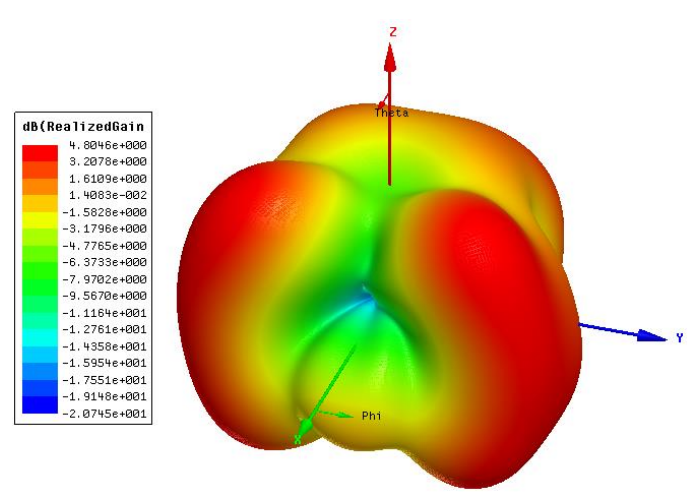

Fig. 5 - Realized gain of 5G monopole antenna at $60 \mathrm{GHz}$

\section{CONCLUSIONS}

This paper presents the $5 \mathrm{G}$ mobile application by implementing single element of monopole microstrip patch antenna which produce acceptable results at $60 \mathrm{GHz}$. The gain performance has reached $4.8 \mathrm{dBi}$ with uniform current distribution. The impedance and radiation characteristics explained that the proposed monopole antenna allows a high data transmission rate for $5 \mathrm{G}$ mobile applications. The proposed antenna achieved the requirements of MMW to operate at the $60 \mathrm{GHz}$ band, in addition to its simple design and easy to be fabricated with a low cost. The achieved results of the proposed antennas made it highly desirable for MMW applications and 5G technology systems and this model is suitable for $5 \mathrm{G}$ mobile applications with high performance and low cost of fabrication.

Fig. 4 - Normalized $E$-field radiation pattern of $5 \mathrm{G}$ monopole antenna at $60 \mathrm{GHz}$ : (a) $x-y$ plane $(E)$, (b) $y-z$ plane $(H)$, and (c) $x-z$ plane

\section{REFERENCES}

1. Dalia M. Elsheakh, Esmat A. Abdallah, Microwave Opt. Technol. Lett. 59 No 1, 189 (2017).

2. D. Imran, M.M. Farooqi, M.I. Khattak, Z. Ullah, M.I. Khan, M.A. Khattak, H. Dar, 2018 International Conference on Engineering and Emerging Technologies (ICEET) (2018).

3. B. Biglarbegian, M. Fakharzadeh, D. Busuioc, M.-R. NezhadAhmadi, S. Safavi-Naeini, IEEE Trans. Anten. Propag. 59 No 5, 1742 (2011).

4. A. Waleed, W. Tanveer Khan, 2017 IEEE MTT-S International Conference on Microwaves for Intelligent Mobility (ICMIM) (2017).

5. Tarek S. Mneesy, Radwa K. Hamad, Amira I. Zaki, Wael A.E. Ali, Appl. Sci. 10 No 13, 4546 (2020).
6. Zahra Hijab, A. Awan Wahaj, A.E. Ali Wael, Hussain Niamat, Abbas, M. Syed, Mukhopadhyay Subhas, Electronics 10 No 4, 405 (2021).

7. W. Ali, S. Das, H. Medkour, S. Lakrit, Microsystem. Technol. 27, 283 (2021).

8. Niamat Hussain, Wahaj Abbas Awan, Wael Ali, Syeda Iffat Naqvi, Abir Zaidi, Tuan Tu Le, AEU - International Journal of Electronics and Communications 132, 153612 (2021).

9. K. Mikko, Radio wave propagation and antenna for millimeter-wave communications, PhD dissertation (Electrical Engineering Dept., Aalto University: Finland: 2013).

10. Saad, R. Ayman Ayd, Hesham A. Mohamed, AEU-International Journal of Electronics and Communications 99, 59 (2019).

11. Fakharzadeh, Mohammad, Mehrbod Mohajer, IEEE Trans. Anten. Propag. 62 No 2, 925 (2013).

\section{Компактна кільцева антена для додатків мобільного зв'язку 5G}

\section{Sarah A. Alassawi ${ }^{1}$, Wael A.E. Ali², Mohamed R.M. Rizk ${ }^{3}$}

\footnotetext{
${ }^{1}$ Electronics \& Comm. Engineering Department, College of Engineering, Higher Institute of Engineering and Technology, King Marriott, Alexandria, Egypt

${ }^{2}$ Electronics \& Comm. Engineering Department, College of Engineering, Arab Academy for Science,

Technology and Maritime Transport (AASTMT), Alexandria, Egypt

${ }^{3}$ Electrical Engineering Department, Alexandria University, Alexandria, Egypt
} 
У роботі представлена альтернативна конструкція несиметричної мікросмугової патч-антени для застосувань бездротового зв'язку у міліметровому (MMW) діапазоні. Метою роботи є обговорення нової конструкції антени, яка працюе у MMW діапазоні на частоті 60 ГГц. Конструкція заснована на одному елементі із загальним розміром $9 \times 11$ мм²$^{2}$, який містить дві еліптичні петлі несиметричної антени та лінію подачі з опором 50 Ом на верхній шар підкладки з частковим заземлювачем на протилежній стороні. Мікросмугова патч-антена розроблена та впроваджена для технології бездротового зв'язку 5G на частоті 60 ГГц з недорогою та малою за розміром підкладкою, що робить її придатною для невеликих пристроїв. У запропонованій конструкції використано матеріал підкладки Roger RT6035htc з відносною діелектричною проникністю 3,5 та тангенсом кута втрат 0,0013 і частковий заземлювач для поліпшення імпедансних характеристик. Спроектована антена забезпечуе рівномірний розподіл струму по поверхні антени на резонансній частоті з прийнятним реалізованим коефіціентом підсилення 4,8 дБі в далекій зоні та зі зворотними втратами, що сягають - 33 дБ. Результати моделювання отримують з використанням симулятору високочастотних структур (HFSS), а FEM базуеться на 3D повнохвильовому електромагнітному симуляторі Ansys. Отримані результати підтверджують придатність запропонованої MMW антени як прийнятного кандидата для додатків 5G.

Ключові слова: MMW, Несиметрична антена, Мобільний додаток 5G, 60 ГГц, Кільцева антена, Симулятор високочастотних структур (HFSS). 